$<$ 症例報告 $>$

\title{
FDG-PET を契機に診断できた肝細胞癌の骨髄転移の一例
}

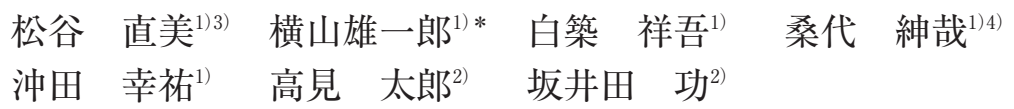

\begin{abstract}
要旨：症例は 70 歳代男性, B 型肝炎ウイルスのキャリアであることを指摘されていたが医療機 関への定期受診はされていなかった. 発熱と倦急感を主訴に前医を受診し, 肝細胞癌と診断され た. CT では明らかな骨転移は指摘されなかったが, 追加検査の FDG-PET では骨皮質の破壊を 伴わないものの骨髄内への集積増加を認めた.引き続き施行した骨髄生検では肝細胞癌の骨髄転 移を認め, cStageIVB と診断した.レンバチニブによる治療を約 9 カ月間行ったが, 口内炎や下 痢，倦㤐感の増悪により投与困難となり，治療開始 10 力月目に死亡退院となった. PIVKA-II 高值の症例では，CT で肝外転移が指摘されなくても FDG-PET を追加施行する意義がある.
\end{abstract}

索引用語： 肝細胞癌＼cjkstart骨髄転移 FDG-PET PIVKA-II レンバチニブ

\section{はじめに}

アテゾリズマブ-ベバシズマブ併用療法やレンバチニ ブ等の免疫チェックポイント阻害剤や分子標的薬の登 場により肝細胞癌に対する治療の選択肢も増えており ${ }^{1)}$, 適切な病期分類の把握が必要となっている. 今回我々 は初診時の CT で骨皮質の破壊は認めずに, FDG-PET を契機に肝細胞癌の骨䯣転移を診断し得た一例を経験 したため, 文献的考察を含めて報告する.

\section{症例}

70 歳代 男性.

主訴：発熱と僚总感.

併存症：B 型肝炎ウイルス (HBV) キャリア.

生活歴：喫煙 20 本/日 $\times 5$ 年, 飲酒機会飲酒, アレ ルギーなし.

紹介時内服薬：ジクロフェナク錠 $25 \mathrm{mg} 1 \mathrm{~T} \times 3$ 回 毎食後, ボノプラザン $20 \mathrm{mg} 1 \mathrm{~T} \times 1$ 回 夕食後.

現病歴：以前より近医で $\mathrm{HBV}$ 感染を指摘されていた が, 医療機関への定期受診はされていなかった. 1 力月

1）独立行政法人地域医療機能推進機構徳山中央病院消 化器内科

2) 山口大学大学院医学系研究科消化器内科学

3) 独立行政法人国立病院機構東京医療センター消化器 科

4）山口県立総合医療センター消化器内科

*Corresponding author: 824yokoyama@gmail.com <受付日2021年3月28日 $><$ 採択日2021年9月1日 $>$
程度続く倦㤐感・発熱のため, 近医を受診し尿路感染 と診断されLVFX を投与されるも改善なく, 精查加療 目的に前医を受診した. 前医で施行された造影 CTでは 肝右葉後区域を中心に両葉に動脈優位相で濃染し, 平 衡相では同病変部の洗い出しを認める腫瘍性病変を認 めた（図 1)。またAFP $1100 \mathrm{ng} / \mathrm{mL} ， P I V K A-I I ~ 9100$ $\mathrm{mAU} / \mathrm{mL}$ と著明な高值を呈しており, 肝細胞癌との診 断で, 加療目的に当院紹介となった.

紹介時現症：血圧 134/87 mmHg, 脈拍 58 回/分, 体 温 36.6 度, 眼瞼結膜 : 蒼白なし, 眼球結膜 : 黄染なし, 呼吸音：清・左右差なし・減弱なし, 心音：杂隹音聴取 なし, 四肢 : 末梢冷感なし下腿浮腫なし. 紹介時血液 検査を示す (表 1 ).

\section{臨床経過}

前医での CT では腹腔動脈周囲リンパ節の腫大を認め た以外は明らかな肝外転移は指摘されていなかったが, AFP や PIVKA-II が著明な高值であったため全身の転 移巣検索目的でFDG-PET を撮影した. 造影 CT の濃染 部位に一致して, 肝右葉後区域に集積増加が認められ た。また，脊椎や腸骨等の骨髄内に集積像を認めた。 骨皮質の破壊はなく，骨髄転移が疑われた（図 2 )。そ のため腸骨から骨髄生検を施行したところ，腸骨脂肪 髄には hyperchromatic で不整な核及び好酸性の胞体を 有する異型細胞の集簇巣が散在し，鍍銀染色で椢状配 列が指摘され (図 3a), 抗 Hepatocyte 抗体での免疫染 色で陽性となった(図 3b)。以上より, 肝細胞癌の多発 


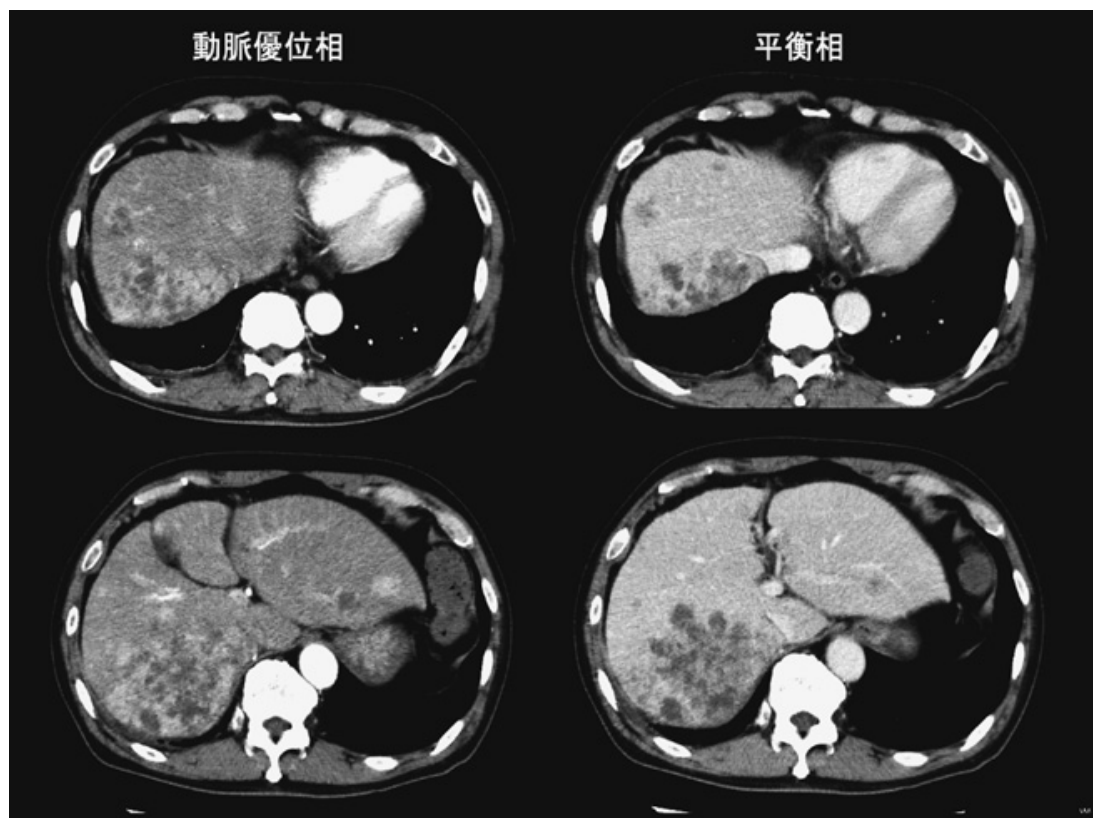

図 1 前医腹部造影 CT

肝右葉後区域を中心として両葉に動脈優位相で濃染し，平衡相で洗い出しを認める腫 瘍性病変を認めた。

表 1 紹介時血液検査

\begin{tabular}{|c|c|c|c|c|c|}
\hline \multicolumn{6}{|c|}{ Blood chemistry } \\
\hline $\mathrm{Alb}$ & $2.7 \mathrm{~g} / \mathrm{dL}$ & HBsAg & $2241.0 \mathrm{IU} / \mathrm{mL}$ & Neutrophil & $65.3 \%$ \\
\hline AST & $41 \mathrm{U} / \mathrm{L}$ & HBV-DNA & $6.5 \mathrm{Log} \mathrm{IU} / \mathrm{mL}$ & Eosinophil & $2.2 \%$ \\
\hline ALT & $32 \mathrm{U} / \mathrm{L}$ & HCVAb & $(-)$ & Lymphocyte & $23.7 \%$ \\
\hline T-Bil & $0.43 \mathrm{mg} / \mathrm{dL}$ & & & & \\
\hline BUN & $18.3 \mathrm{mg} / \mathrm{dL}$ & Peripheral & & Coagulation test & \\
\hline Cre & $0.94 \mathrm{mg} / \mathrm{dL}$ & WBC & $6960 / \mu \mathrm{L}$ & PT & $123 \%$ \\
\hline $\mathrm{Na}$ & $139 \mathrm{mmol} / \mathrm{L}$ & $\mathrm{RBC}$ & $394 \times 10^{4} / \mu \mathrm{L}$ & PT & 11.2 秒 \\
\hline $\mathrm{Cl}$ & $105 \mathrm{mmol} / \mathrm{L}$ & $\mathrm{Hb}$ & $12.1 \mathrm{~g} / \mathrm{dL}$ & APTT & 37.1 秒 \\
\hline CRP & $8.46 \mathrm{mg} / \mathrm{dL}$ & $\mathrm{Ht}$ & $36.0 \%$ & & \\
\hline $\mathrm{AFP}$ & $1217.5 \mathrm{ng} / \mathrm{mL}$ & Plt & $35.0 \times 10^{4} / \mu \mathrm{L}$ & & \\
\hline PIVKA-II & $20749 \mathrm{mAU} / \mathrm{mL}$ & $\mathrm{MCV}$ & $91.4 \mathrm{fl}$ & & \\
\hline
\end{tabular}

骨䯣転移で cStage IVB（T3N1M1）と診断した。発熱 が持続し，食事摂取の低下により低アルブミン血症を 認め, Child-Pugh スコア 7 点ではあったが, 肝癌診療 ガイドライン ${ }^{2)}$ に従って分子標的薬であるレンバチニブ による治療を開始した. 導入直後は PIVKA-II の著増を 認めたが，その後は低下した.レンバチニブによる治 療に伴って高血圧や嗄声, 甲状腺機能低下, 下痢など の各種副作用を認めたが対症療法で対応した。投薬開
始後 4 力月に慰部の皮下膿瘍を認めたためレンバチニ ブを一時休薬した.レンバチニブ投与 3 力月の腹部 CT 画像で肝内に新病変を認め, mRECIST で PD の評価に なるが, 右葉後区域の主病変は明らかな増大傾向にな く, 血流も低下傾向にあったため, 治療を再開した(図 4). 治療開始 10 力月目には倦总感, 口内炎や下痢の増 悪を認め, 食事摂取困難となり，レンバチニブ投与継 続困難となった。治療中止後に急激に全身状態が悪化 
(a)

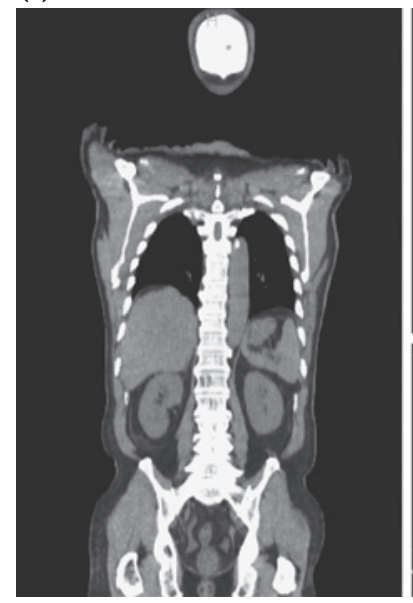

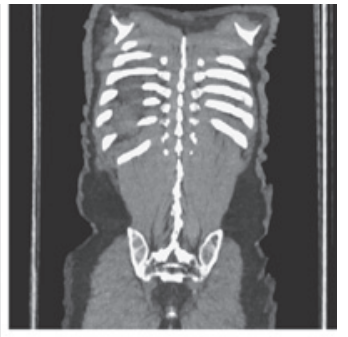

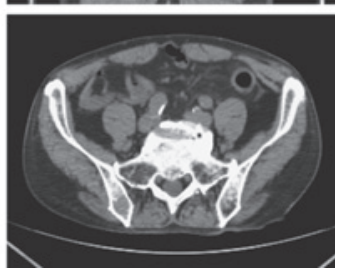

(b)

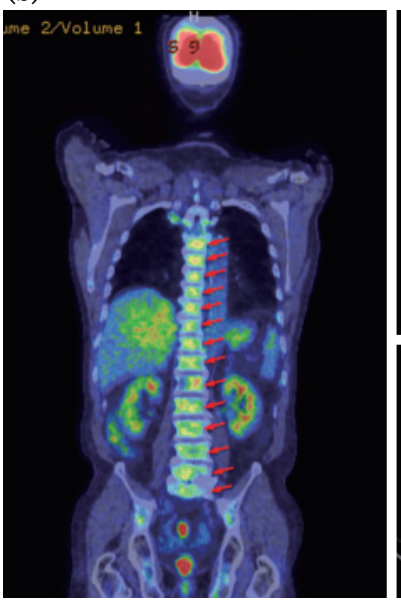

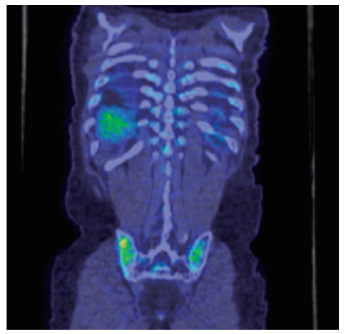

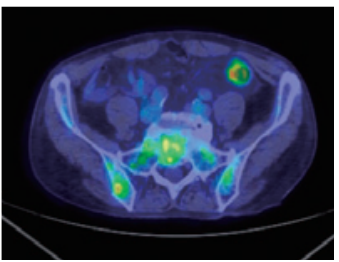

図 2 当院 FDG-PET CT

（a）単純 CT：明らかな骨皮質の破壊像は認められない（b）FDG-PET CT：春椎の広範囲の骨髄内に集積増加を認 める (矢印)。腸骨の骨䯣内にも集積増加あり。

(a)

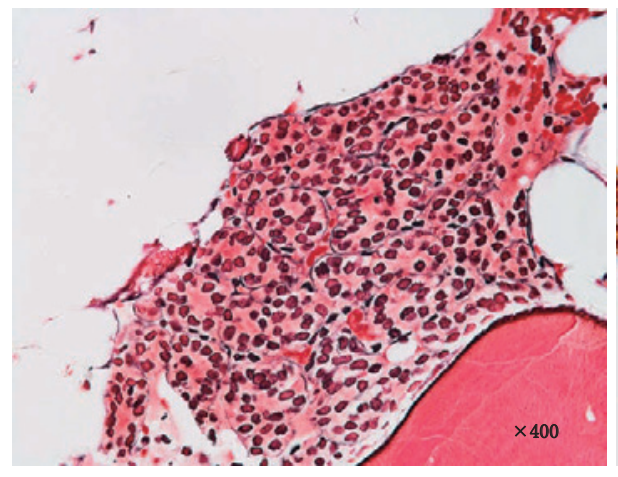

(b)

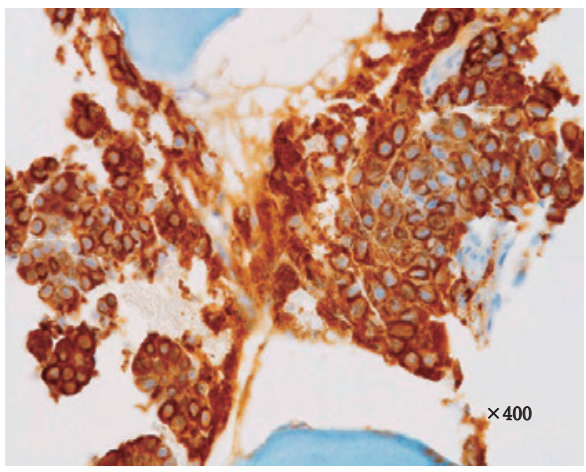

図 3 腸骨骨髄生検

（a）鍍銀染色：脂肪髄には hyperchromatic で不整な核を有する異型細胞の柵状配列を観察す

る.（b）免疫染色：異型細胞は抗 Hepatocyte 抗体陽性となった。

し死亡に至った. 図 5, 図 6 に, 初診から死亡退院まで の PIVKA-II, AFP, LDH, ALPについて示した。レ ンバチニブ投与中に相関して数值の低下を認め, 皮下 膿瘍による投与中断後より継時的な上昇を認めた。

\section{考察}

骨髄転移の様な肝外転移については, 肝癌診療ガイ ドライン ${ }^{2)}$ では治療後の経過中に出現する頻度は21〜24\% (肺：6〜29\%,リンパ節：5〜20\%, 骨 : 2〜10\%, 副腎： $1 \sim 10 \%$, 脳： $0.2 \sim 0.6 \%)$ と報告され, その危険因子と しては, PIVKA-II> $300 \mathrm{mAU} / \mathrm{mL}$, 門脈腫瘍栓あり,
血小板数 $\leqq 130 \times 10^{3} / \mu \mathrm{L}$, 肝予供能が保たれている症例, 食道静脈瘤なし等が記載されている。 一方で年齢, 血 中アルブミン值，ビリルビン值や Prothrombin time (PT)については肝外転移との関連性はないといわれて いる ${ }^{5)}$. 初発時点では 1.0 2.3\% と肝外転移の頻度は低 く, 危険因子についての言及はない(6)7).

本症例は, 肝細胞癌の骨髄転移の症例であったが, 医学中央雑誌にて “肝細胞癌”, “骨髄転移”, PubMed にて“hepatocellular carcinoma”, "bone marrow metastasis”で検索したところ臨床経過を詳細に確認できた のは 2 編の論文のみであった ${ }^{3 / 4}$.この 2 編はいずれも 


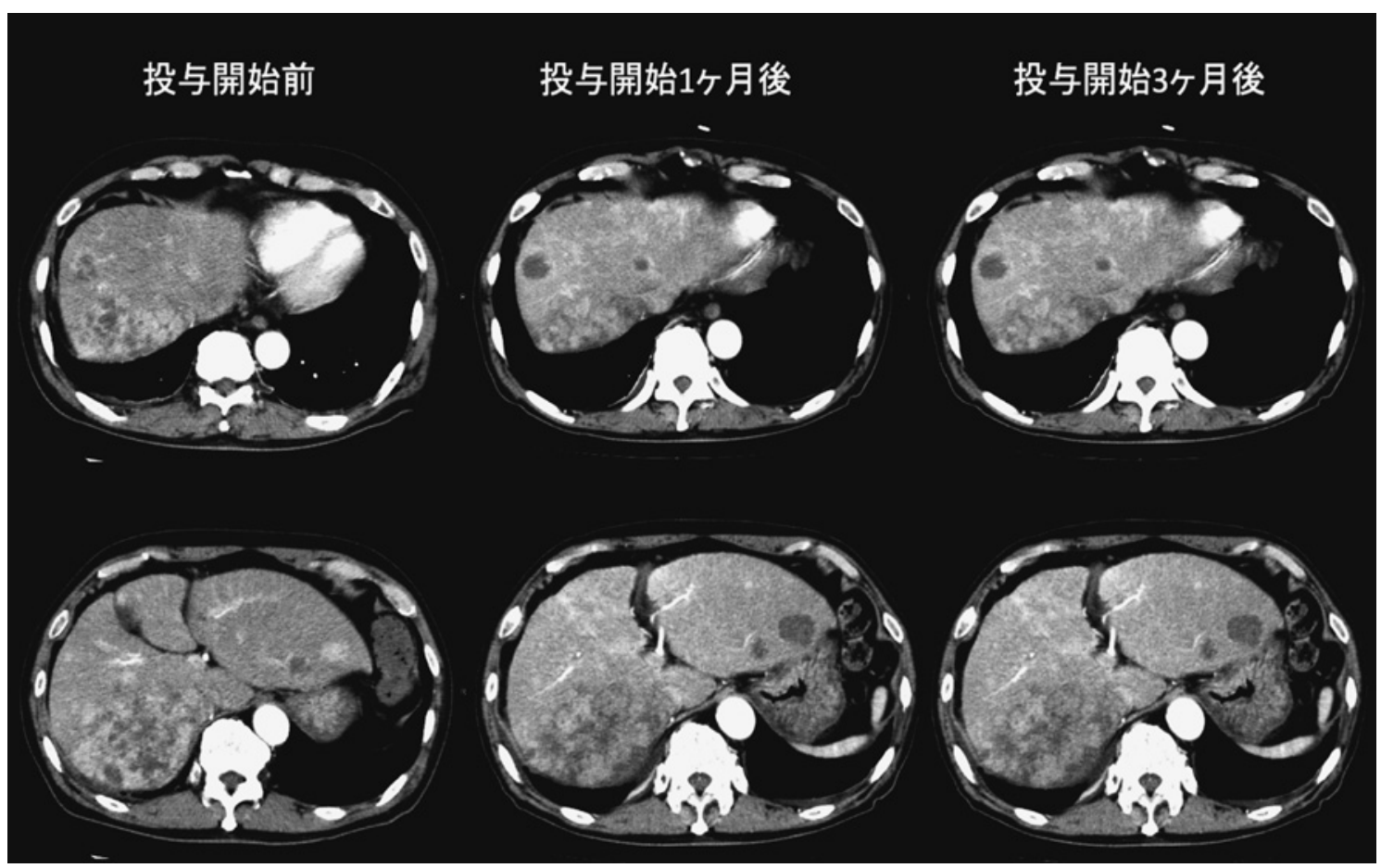

図 4 腹部造影 CT（動脈優位相）

肝右葉後区域の主病変は明らかな増大傾向になく, 血流も低下傾向にあった.

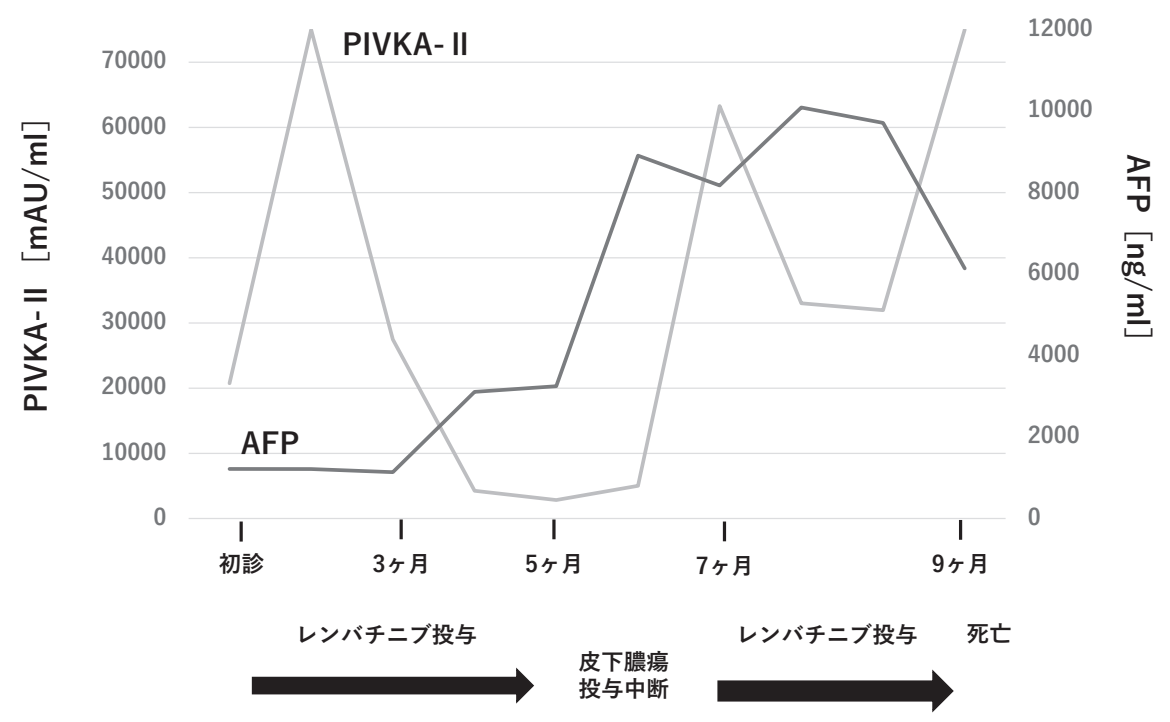

図 5 腫瘍マーカーの推移

初診時から死亡退院までの AFP およびPIVKA-II の推移を示した. PIVKA-II はレンバ チニブ投与開始および再開後には著明に増加したが，その後低下を認めている。AFPは レンバチニブ投与開始後しばらく横ばいであったが, その後は増加傾向にあった. 


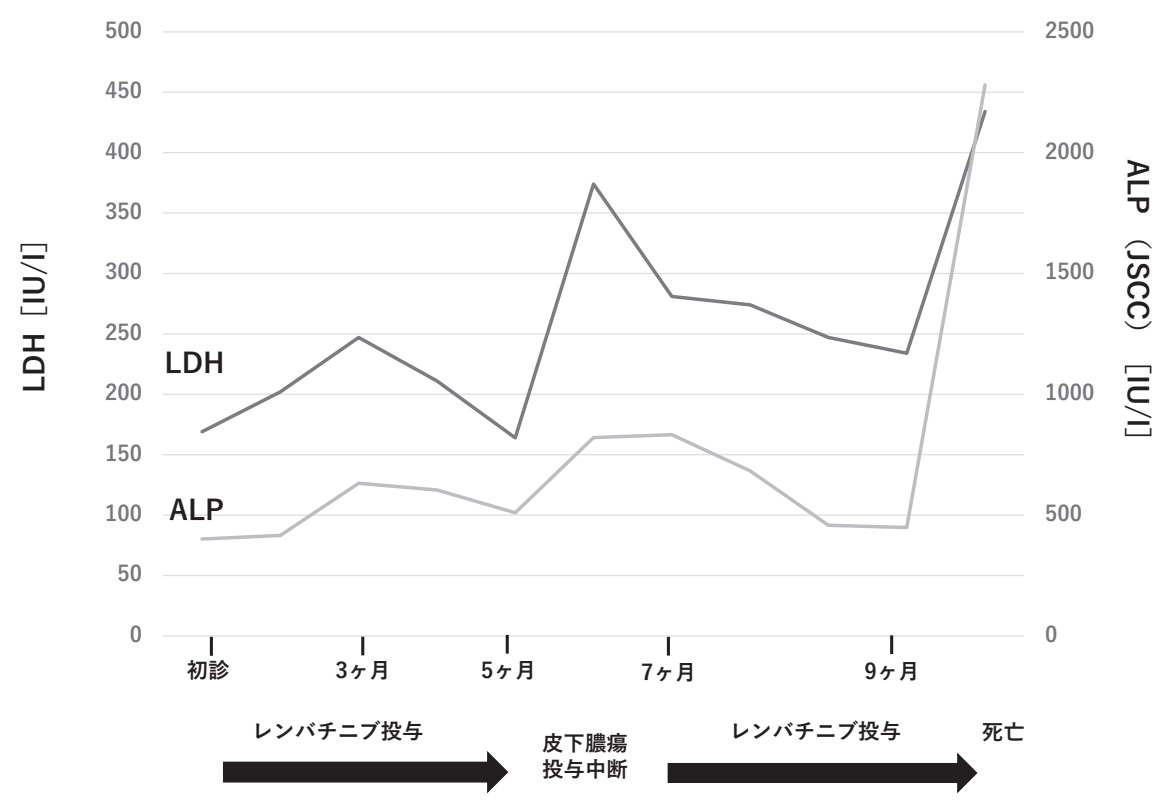

図 6 ALP およびLDH の推移

初診時にはいずれも高值を示さなかったが, 皮下膿瘍によるレンバチニブ投与中断後よ り継時的な上昇を認めた. レンバチニブ再開により低下傾向になったが, 全身状態の悪 化に伴うレンバチニブ中止後より再上昇した.

肝細胞癌による播種性骨髄癌症 (Disseminated carcinomatosis of the bone marrow：DCBM）の症例報告であ り，汎血球減少をきっかけに骨䯣生検を施行し，骨髄 転移が診断されている. DCBM も頻度は低いが, 出血 傾向や腰痛，貧血の 3 徴を認めた際には念頭に置いて おくべき病態であり，急速な増悪の経過を辿る症例の 多い DCBM を疑った際には積極的に骨髄生検や FDGPET を施行することが推奨される ${ }^{3)}$. 本症例は 3 徵を認 めてはいなかったものの, 骨髄転移を認めていたこと を含め, 長期生存があれば DCBM の上記 3 徵を認めて いた可能性も否定できないと考えられた.

既報の骨髄癌腫症の 2 例と本症例を示す（表 2). 3 症例と少ない検討であるが, 本症例を除き DCBM の 2 症例は若年発症であった。本症例を含め 2 症例は, 発 熱を主訴として病院を受診されている。偶然かもしれ ないが 3 症例ともに $\mathrm{HBV}$ キャリアであったが, 定期的 なフォローアップは受けられていなかった．定期的な フォローアップを受けていなかったことも骨髄転移の ような肝外転移まで進行して診断された原因の一つと 考えられた。また，骨髄にはリンパ管は存在しないと 考えられており，骨髄転移の機序としてリンパ行性転 移は否定され，血行性転移が主体と考えられている。
遺伝子パスウェイ/ネットワーク解析を用いた検討によ ると B 型慢性肝炎では血管新生に関わるパスウェイの 立進が認められており ${ }^{8)}, \mathrm{HBV}$ 関連の肝細胞癌では血行 性転移を起こしやすい素地があるのかもしれない。

血行性骨髄転移は大循環型が主となりその所見とし ては, 多発性骨髄転移, 骨髄洞内の腫瘍塞栓, 骨皮質 破壊を伴わない骨髄転移, 他臓器の多発性転移等が挙 げられる ${ }^{9)}$. 他臓器の転移を経由する事なく骨や骨髄に 転移する機序としては脊椎静脈系経路の存在が指摘さ れている。脊柱管周囲に分布する内椎骨静脈叢, 脊椎 椎体前面に分布する外椎骨静脈叢, 及び両者を結ぶ椎 体静脈を脊椎静脈系と呼ぶ。脊椎静脈系では静脈弁を 認めず，胸腔内圧や腹圧が上昇すると容易に血液が逆 流すると考えられている，肝硬変を合併した肝細胞癌 症例では，門脈圧立進により側副血行路が発達し，奇 静脈への血流量が増加し，その血圧が上昇する。脊椎 静脈系は奇静脈系とも交通があるため, 癌細胞が無弁 の脊椎静脈系を逆流して脊椎や脊髄に転移することが 十分に考えられるとされている ${ }^{10)}$. Hong らの報告症例 では門脈腫瘍栓を認めず肺転移をみとめていることか ら大循環型の転移を推測する. Honda らの報告症例や 本症例では，肺を含めた多臓器への転移は認めていな 
表 2 骨髄転移症例の検討

\begin{tabular}{|c|c|c|c|}
\hline 症例 & Hong YM, et al. ${ }^{3)}$ & Honda Y, et al. ${ }^{4)}$ & 本症例 \\
\hline プロフィール & 58 歳 男性 & 50 歳 男性 & 70 歳代 男性 \\
\hline 症状 & 倦㤐感·体重減少 & 発熱·腰痛 & 発熱·倦㤐感 \\
\hline 主病変サイズ & $50 \mathrm{~mm}$ & $36 \mathrm{~mm}$ & $93 \mathrm{~mm}$ \\
\hline 成因 & $\mathrm{HBV}$ & $\mathrm{HBV}$ & $\mathrm{HBV}$ \\
\hline 転移部位 & 骨髄・肺・リンパ節 & 骨髄・腰椎・リンパ節 & 骨髄・リンパ節 \\
\hline $\mathrm{WBC}(/ \mu l)$ & 記載なし & 18230 & 6960 \\
\hline $\mathrm{Hb}(\mathrm{g} / \mathrm{d} l)$ & 11.0 & 14.3 & 12.1 \\
\hline 血小板数（万/ $\mu l ）$ & 5.2 & 12.8 & 35.0 \\
\hline $\operatorname{ALP}(\mathrm{U} / l)$ & 記載なし & 648 & 401 \\
\hline $\mathrm{LDH}(\mathrm{U} / l)$ & 記載なし & 293 & 169 \\
\hline PIVKA-II $(\mathrm{mAU} / \mathrm{m} l)$ & 295 & 2403 & 20749 \\
\hline $\operatorname{AFP}(\mathrm{ng} / \mathrm{m} l)$ & 15.62 & 13.8 & 1217.5 \\
\hline 門脈腫瘍栓 & なし & あり & なし \\
\hline 食道静脈瘤 & なし & なし & なし \\
\hline 診断から死亡まで & 約 2.3 力月 & 20 日 & 約 12 力月 \\
\hline
\end{tabular}

いことから脊椎静脈系経路の転移を考えるところであ るが, 2 症例ともに食道静脈瘤は認めず, 門脈圧充進を 示唆する所見は見当たらなかった，しかし，脊椎静脈 系経路の転移は前立腺癌の骨転移の機序としても考え られており ${ }^{11)}$, 門脈圧元進状態でなくても脊椎静脈系の 血流の逆流は起こりうると考えられ，この 2 症例は脊 椎静脈系経路の骨髄転移の可能性が高いと推察する.

腫瘍マーカーに関しては, 本症例を除く 2 症例の AFP はわずかな上昇にとどまっているが, 3 症例ともに肝癌 診療ガイドラインで述べられているようにPIVKA-II の高值を認めている. PIVKA-II に関しては肝細胞癌が 積極的に PIVKA-II を産生するわけではなく Epithelial mesenchymal transition（EMT）の過程においてアク チン線維が断裂することにより脂溶性ビタミンである ビタミン K の取り込みが不良となり, プロトロンビン 前駆体から活性型プロトロンビンへの変換が不良とな るため, PIVKA-II が産生されると考えられている ${ }^{12}$. EMT が誘導された癌細胞は浸潤能や転移能を獲得する とされて抢り,血中 PIVKA-II 高值の症例は血管浸潤や 転移のリスクが高いとされている ${ }^{13}$.

昨今, 良性・悪性腫瘍の診断や病期診断のため FDGPET が行われており ${ }^{14)}$, 適切な治療法を選択するため にも正確な病期分類を行うことが重要となる ${ }^{15)}$.一般的 に悪性細胞は細胞膜上にグルコーストランスポーター (GLUT) が過剩に発現しており, 腫瘍細胞内へのグル コースの取り込みが充進している.グルコースと類似 の構造を持つ FDG は腫瘍細胞に取り込まれるが, 解糖
系に進むことができずに腫瘍細胞に蓄積するという特 徵がある。一方で肝細胞癌では解糖系しか行わない他 の細胞と違い, グリコーゲン生成や貯蔵のために Glucose6-Phosphatase（G-6-Pase）を豊富に持つ肝細胞本来の 性質を持っている，そのために G-6-Pase によって，再 び脱リン酸化されて一部の高分化型肝細胞癌では FDG は肝細胞癌の外に放出されしばしば偽除性を示すこと があり ${ }^{16)}$, 肝細胞癌の原発巣の評価には推奨されていな ( ${ }^{14)}$. しかし, 肝細胞の表現型が変化するためか, 肝外 転移巣の検出には優れており, FDG-PET は肝外転移の 評価には適すると報告されている ${ }^{14177}$. 本症例では FDGPET を契機に骨髄転移が診断され, 病期分類には FDGPET は非常に有用であった. 他の 2 症例も肝外転移の 状態を確認するものとして FDG-PETを利用していた.

今回の症例のように, FDG-PET では骨に集積がみら れたものの, CT では骨皮質の破壊像がみられずに所見 の乘離がみられたが, CT は骨皮質や骨梁の構築を破壊 しない骨髄転移のような病態の検出能は不良である ${ }^{18}$. このような場合では, 診断確定のためにも FDG-PET で集積を認めた部位から骨䯣生検を行い, 癌細胞を検 出することが重要である，また，既報の 2 症例では骨 䯣生検を施行することで, DCBM の診断に至っており, 造血機能障害の原因や病状の進行まで確認できている. しかし, 集積を認めた部位によっては骨髄生検が困難 な場合もあり, そのような場合には, 骨髄の変化を詳 細に画像化できる MRI が有用で, 骨髄転移巣はT1 強調画像で低信号域として明瞭に描出され, 検出率も 
かなり高いとされている ${ }^{19) 20)}$. 治療前に骨髄転移巣を MRI で評価した際には，治療効果判定も比較的容易におこ なえる利点もある.

今回検討した骨髄転移の 3 症例とも診断から 1 年以 内に死亡されており,特にDCBM になれば非常に予後 不良である。肝細胞癌の治療法の進歩や肝予備能が良 好な肝細胞癌の症例の増加により骨髄転移症例も増加 するものと考えられ，早期発見が重要である。骨髄転 移を含めた肝外転移を早期発見するには FDG-PET を用 いた全身検索が有用であり，特に肝内病変に比し， PIVKA-II が高值を示す症例では追加施行する意義があ ると考える.

\section{結語}

今回 CT では指摘できなかった肝細胞癌の骨髄転移を FDG-PETを契機に診断しえた一例を経験した. 肝細胞 癌の治療として免疫チェックポイント阻害剤や分子標 的薬の登場もあり，正確な病期診断のためにも肝外転 移巣の検出に優れている FDG-PET の必要性が増してい ると考えられた。 なお, 今回の症例は第 43 回日本肝蔵 学会西部会で報告した.

\section{文献}

1）小林正宏. 新規分子標的薬レンバチニブと肝癌薬物 療法の展望. 日本消化器病学会雑誌 $2019 ; 116$ ： $36-44$

2) 日本肝臓学会編編，「肝癌診療ガイドライン 2017 年版第 4 版」

3) Hong YM, Yoon KT, Cho M, et al. Bone marrow metastasis presenting as bicytopenia originating from hepatocellular carcinoma. Clin Mol Hepatol 2016; 22: $267-271$

4) Honda Y, Kawaoka T, Aikata H, et al. Disseminated carcinomatosis of the bone marrow originating from hepatocellular carcinoma. A case report. Hepatology Research 2015; 45: 705-710

5) Bae HM, Lee JH, Yoon JH, et al. Protein induced by vitamin $\mathrm{K}$ absence or antagonist-II production is a strong predictive marker for extrahepatic metastases in early hepatocellular carcinoma: a prospective evaluation. BMC cancer 2011; 11: 435

6) Natsuizaka M, Omura T, Akaie T, et al. Clinical features of hepatocellular carcinoma with extrahepatic metastases. J Gastroenterol Hepatol 2005; 20: $1781-1787$
7) Uchino K, Tateishi R, Shiina S, et al. Hepatocellular carcinoma with extrahepatic metastasis. clinical features and prognostic factors. Cancer 2011; 117: 4475-4483

8) Honda M, Yamashita T, Ueda T, et al. Different signaling pathways in the livers of patients with chronic hepatitis B or chronic hepatitis C. Hepatology 2006; 44: 1122-1138

9）森脇昭介, 万代光一, 山上啓太郎. 骨髄転移の病理 形態と問題点. 病理と臨床 $1999 ; 17: 27-34$

10）浦野 透, 安積正作, 前谷二郎, 他. 奇静脈及び脊 椎静脈系を介して今日ついに転移したと考えられる 肝細胞癌の 1 剖検例。肝蔵 $1992 ; 38 ： 484-488$

11) Batson OV. The function of the vertebral veins and their role in the spread of metastases. Annals of Surgery 1940; 112: 138-149

12）熊田 卓, 豊田秀徳, 多田俊史, 他. 腫瘍マーカー. 日本臨牀 2018；76：195-202

13) Suzuki H, Murata K, Gotoh T, et al. Phenotypedependent production of des- $\gamma$-carboxy prothrombin in hepatocellular carcinoma. J Gastroenterol 2011; 46: 1219-1229

14）塩見 進, 小谷晃平, 東山滋明, 他. 画像診断 FDGPET による肝細胞癌の診断．日本臨牀 $2015 ; 73$ (増刊号) : 559-563

15) Kawamura E, Shiomi S, Kotani K, et al. Positioning of F-FDG PET imaging in the management algorithm of hepatocellular carcinoma. J Gastroenterol Hepatol 2014; 29: 1722—1727

16）調 憲, 王 歓林, 今井大祐, 他. FDG-PET による肝癌悪性度診断. 日本臨牀 $2015 ； 73 ： 568$ 571

17) Sugiyama M, Sakahara H, Torizuka T, et al. 18 FFDG-PET in the detection of extrahepatic metastases from hepatocellular carcinoma. J Gastroenterol 2004; 39: 961—968

18）原田宏海, 田邊芳雄, 島谷康彦, 他. 骨梁間型骨転 移を来した肺小細胞癌の 1 例. 臨床核医学 2004 ； $37: 53-55$

19）栗山啓子, 門田 強, 黒田知純, 他. 肺小細胞癌の 骨髄転移の MRI 診断. 肺癌 $1991 ； 31 ： 497-502$

20) Yamaguchi T, Tamai K, Yamato M, et al. Intertrabecular pattern of tumors metastatic to bone. Cancer 1996; 78: 1388-1394

本論文内容に関連する著者の利益相反：なし 


\title{
A case of bone marrow metastasis of hepatocellular carcinoma diagnosed by fluorodeoxy glucose-positron emission tomography
}

\author{
Naomi Matsutani ${ }^{13)}$, Yuichiro Yokoyama ${ }^{1)}$, Shogo Shiratsuki ${ }^{1)}$, Shinya Kuwashiro ${ }^{144)}$, \\ Kosuke Okita ${ }^{1)}$, Taro Takami ${ }^{2}$, Isao Sakaida ${ }^{2)}$
}

The patient was a man in his 70s. He had been a carrier of hepatitis B virus. However, he had not undergone clinical treatment regularly. He visited a physician due to fever and fatigue and was diagnosed with hepatocellular carcinoma (HCC). Computed tomography (CT) did not show bone metastasis, but fluorodeoxyglucosepositron emission tomography (FDG-PET) showed abnormal uptake of the bone marrow without destruction of the bone cortex. Bone marrow biopsy showed metastasis of HCC. The patient was diagnosed with HCC cStage IVB. He was treated with lenvatinib for 9 months, but it was discontinued due to stomatitis, diarrhea, and severe fatigue. The patient died 10 months after initiation of treatment.

A high PIVKA-II level increases the risk of extrahepatic metastasis. Therefore, we suggest checking the FDG-PET even if it does not show extrahepatic metastasis by CT.

Key words: hepatocellular carcinoma bone marrow metastasis FDG-PET PIVKA-II lenvatinib

Kanzo 2022; 63: 16-23

1) Department of Gastroenterology, Tokuyama Central Hospital, Yamaguchi, Japan

2) Department of Gastroenterology and Hepatology, Yamaguchi University Graduate School of Medicine, Yamaguchi, Japan

3) Department of Gastroenterology, National Organization Tokyo Medical Center, Tokyo, Japan

4) Department of Gastroenterology, Yamaguchi Prefectural Grand Medical Center, Yamaguchi, Japan

${ }^{*}$ Corresponding author: 824yokoyama@gmail.com

(C) 2022 The Japan Society of Hepatology 